\title{
Derap Langkah Pemuda sebagai Fasilitator Majelis Pemberdayaan Masyarakat Pimpinan Pusat Muhammadiyah di Tempat Pembuangan Sampah Terpadu (TPST) Piyungan
}

\author{
Muhammad Rifa'at Adiakarti Farid \\ Universitas Muhammadiyah Yogyakarta \\ Email: rifaatfarid@gmail.com
}

\begin{abstract}
This dedication provides an overview of empowerment efforts for scavengers in TPST Piyungan. The focus of assistance is aimed at preventing and managing disease that threatens scavengers. The purpose of this study is (1) To find out the problems faced by the Community Empowerment Council (MPM) in carrying out community empowerment programs in TPST Piyungan. (2) Knowing the impact of community empowerment programs conducted by MPM in TPST Piyungan (3) Knowing the role and participation of youth in community empowerment programs carried out by MPM at TPST Piyungan. This research uses descriptive qualitative method. The results showed (1) Problems faced by MPM came from the surrounding community who did not know the empowerment program in detail (2) Impacts that occurred in the community were united in a community that had been scattered in several collectors groups and better understood their potential (3) Youth who are members of the community empowerment facilitator play an active role in conducting empowerment programs.
\end{abstract}

Abstrak: Pengabdian ini memberikan gambaran upaya pendampingan bagi pemulung di TPST Piyungan. Fokus pendampingan ditujukan pada pencegahan dan penanggulangan pemyakit yang mengancam pemulung. Tujuan penelitian ini adalah (1) Mengetahui masalah yang dihadapi Majelis Pemberdayaan Masyarakat (MPM) dalam menjalankan program pemberdayaan masyarakat di TPST Piyungan. (2) Mengetahui dampak program pemberdayaan masyarakat yang dilakukan oleh MPM di TPST Piyungan (3) Mengetahui peran dan partisipasi pemuda dalam program pemberdayaan masyarakat yang dilakukan oleh MPM di TPST Piyungan. Penelitian ini menggunakan metode kualitatif deskriptif. Hasil penelitian menunjukkan (1) Masalah yang dihadapi MPM berasal dari masyarakat sekitar yang belum mengetahui program pemberdayaan secara detail (2) Dampak yang terjadi di masyarakat adalah bersatu dalam satu komunitas yang dahulu terpencar dalam beberapa kelompok pengepul dan lebih memahami potensi diri (3) Pemuda yang tergabung dalam fasilitator 
pemberdayaan masyarakat berperan aktif dalam melakukan program pemberdayaan.

Kata Kunci: Partisipasi, Peran Pemuda, Pemberdayaan Masyarakat

\section{PENDAHULUAN}

Sejak lahirnya pada 1912, inti dari gerakan Muhammadiyah sering diringkas dalam tiga kata: feeding (santunan dan pemberdayaan), schooling (pendidikan), dan healing (pengobatan dan penyehatan). Tiga gerakan inilah yang menyebabkan Muhammadiyah mampu memiliki 7.227 PAUD, TK, TPA, dan SD/MI; 2.915 SMP/ MTs, SMA/MA, dan SMK; 67 pesantren; 172 universitas, akademi, dan politeknik; 457 rumah sakit, klinik, dan poliklinik; serta 454 panti asuhan, rumah jompo, dan pusat rehabilitasi cacat (Maarif, 2012).

Tidak ada ormas Islam dari negara manapun yang memiliki amal usaha sebanyak yang dimiliki oleh Muhammadiyah. Konsep dan praktik amal usaha yang dilakukan oleh Muhammadiyah saat ini berbeda dari Muhammadiyah periode awal. Apa yang dilakukan Muhammadiyah pada dekade belakangan ini tidak bisa masuk pada definisi murni dari "amal usaha" dimana sebuah kegiatan sosial hanya berharap pahala akhirat dan orientasinya adalah untuk membantu orang miskin, terpinggirkan, tertindas maupun terabaikan yang tidak menjadi perhatian serius pemerintah maupun pihak swasta lainnya seperti yang dikatakan oleh Said Tuhuleley, pimpinan Majelis Pemberdayaan Masyarakat Muhammadiyah periode 2005-2010.

"Amal usaha Muhammadiyah pun dikelola sebagai industri jasa dan dilepaskan dari pengarusutamaan pemberdayaan rakyat miskin, sebagaimana Muhammadiyah pada periode awal ketika masih dipimpin KH Ahmad Dahlan" (Tuhuleley, 2015).

Setelah Muktamar Muhammadiyah di Jakarta tahun 2000, berdiri sebuah Lembaga di lingkup Muhammadiyah yang menangani pemberdayaan masyarakat dengan nama Lembaga Buruh Tani dan Nelayan (LBTN). Hasil Muktamar Muhammadiyah di Malang tahun 2005, lembaga ini berubah menjadi Majelis Pemberdayaan Masyarakat (MPM) sebagai upaya menggali dan mengangkat kembali prinsip yang melandasi gerak Muhammadiyah pada periode awal berdiri. Hal ini sebagai upaya memaknai dan mengimplementasikan dalam bentuk gerakan sosial baru yang lebih relevan dan sesuai dengan perkembangan zaman. Prinsip dari gerakan Muhammadiyah awal yang hendak dibangkitkan kembali pasca Muktamar 2005 di Malang itu terutama adalah humanisme non-sektarian. 
Muhammadiyah akan menolong sesama manusia tidak membedakan. Prinsip ini mengacu pada berbagai dokumen sejarah yang menyebutkan bahwa:

"Pertolongan Moehammadijah b/g PKO itoe, boekan sekali-sekali soeatoe djaring kepada manoesia oemoemnja, soepaja dapat menarik hati akan masoek kepada agama Islam atau perserikatan Moehammadijah, itoe tidak, akan tetapi segala pertolongannja itoe semata-mata karena memenoehi kewadjiban atas agamanja Islam terhadap segala bangsa" (Almanak Moehammadijah 1929).

Prinsip itu diterjemahkan oleh Majelis Pemberdayaan Masyarakat (MPM), di bawah pimpinan pertamanya Said Tuhuleley pasca Muktamar tahun 2005 di Malang, dalam bentuk pemberdayaan dan pertolongan kepada semua masyarakat tanpa memandang latar belakang agama dan golongan. Ini misalnya, diwujudkan dalam bentuk bantuan dan advokasi terhadap komunitas Syiah Sampang yang mengalami diskriminasi dan pengusiran. Ketika banyak lembaga filantropi yang enggan membantu Syiah karena dianggap sebagai komunitas sesat, Muhammadiyah tak ragu ikut membantu dan mendampingi mereka.

Di era globalisasi ini perkembangan zaman yang sangat pesat masih ada saja masyarakat yang hidup di bawah garis kemiskinan. Muhammadiyah dalam melakukan kegiatan pemberdayaan masyarakat melalui Majelis Pemberdayaan Masyarakat (MPM) selama ini sangat gencar dalam membantu perekonomian masyarakat menengah ke bawah melalui pemberdayaan-pemberdayaan yang dilakukannya.

Tupoksi MPM yang fokus dalam pemberdayaan dan pertolongan semua masyarakat diterjemahkan ke dalam struktur organisasi, dimana satu orang ketua dan 5 wakil ketua. Dalam melaksanakan tugasnya selain adanya beberapa divisi, juga terdapat konsultan ahli yang berperan sebagai pemberi masukan, pertimbangan maupun nasihat dalam melakukan pemberdayaan masyarakat. Adapun fasilitator menjadi garda terdepan MPM dalam melakukan program pemberdayaan.

\section{GAMBARAN UMUM TPST PIYUNGAN DAN METODE PENDAMPINGAN}

Permasalahan sampah berbagai daerah di Indonesia memang tidak ada habisnya. Begitu pula yang dialami oleh Daerah Istimewa Yogyakarta. Jumlah penduduk Daerah Istimewa Yogyakarta semakin bertambah setiap tahun dengan laju pertumbuhan yang berfluktuasi. Bertambahnya jumlah penduduk berbanding lurus dengan peningkatan timbunan sampah. 
Selain bertambahnya jumlah penduduk, peningkatan timbunan sampah juga disebabkan oleh peningkatan aktivitas serta belum semua pihak mempunyai kemampuan maupun kemauan dalam mengelola sampah.Sementara itu, peningkatan timbunan sampah tidak diimbangi dengan ketersediaan lahan pembuangan sampah yang memadahi sehingga menyebabkan kapasitas Tempat Pembuangan Sampah Terpadu (TPST) di Yogyakarta semakin menurun.

Daerah Istimewa Yogyakarta memiliki tiga tempat pembuangan akhir, yakni TPST Piyungan, TPST Banyuroto dan TPST Baleharjo. TPST Piyungan menampung jumlah sampah terbesar karena merupakan tempat pembuangan sampah akhir bagi Kota Yogyakarta, Kabupaten Sleman dan Kabupaten Bantul. Kondisi TPA Piyungan kian lama kian memprihatinkan karena kapasitasnya sebagai lokasi penampungan akhir sampah sudah mengalami penurunan.

Tabel 1.1 Volume Sampah di TPA Piyungan Tahun 2013 - 2018

\begin{tabular}{ccc}
\hline \hline No & Tahun & Jumlah (kg) \\
\hline \hline 1 & 2013 & 116.390 .909 \\
\hline 2 & 2014 & 80.794 .724 \\
\hline 3 & 2015 & 111.032 .545 \\
\hline 4 & 2016 & 123.033 .664 \\
\hline 5 & 2017 & 130.826 .234 \\
\hline 6 & $2018^{*}$ & 94.831 .783 \\
\hline
\end{tabular}

Total volume sampah $\quad 656.909 .859$

Keterangan : 2017 = jumlah sampah dari Januari - Oktober 2018

TPST Piyungan didirikan pada tahun 1995 dan mulai beroperasi pada tahun 1996 dengan luas lahan 12,5 Ha kemudian diperluas menjadi $14 \mathrm{Ha}$.TPST Piyungan dikelola oleh Sub Dinas Cipta Karya Dinas Pekerjaan Umum Propinsi Daerah Istimewa Yogyakarta pada tahun 1996 s/d 1999. Namun, dengan adanya Undang-undang No. 22 Tahun 1999 tentang Pemerintah Daerah, sejak tahun 2000 pengelolaan TPST Piyungan dilakukan bersama oleh Kabupaten Sleman, Kota Yogyakarta dan Kabupaten Bantul dalam wadah kerjasama Sekretariat Bersama Kartamantul. (Ardila, 2017).

TPST Piyungan terletak pada cekungan dengan kemiringan bervariasi, curam, dan mendatar. Lokasi tempat TPST Piyungan berdiri terbentuk atas tanah ledok dengan jurang yang cukup dalam sebesar $40 \mathrm{~m}$. Kedalaman airtanah berkisar antara 2-5 meter dengan lapisan tanah mengandung gamping. Luas keseluruhan TPST Piyungan sebesar 12,5 Ha dengan kapasitas volume sampah 
2.7 juta m3 . Saat ini TPST Piyungan merupakan tempat pembuangan akhir regional dari tiga Kabupaten yaitu Kota Yogyakarta, Sleman, dan Bantul. Sampah yang masuk ke TPST Piyungan berkisar antara 400-500 ton/hari dengan sistem pengelolaan sampah control landfill.

Sampah yang dikirim ke TPST Piyungan bisa mencapai 450 - 500 ton perhari. Kepala Seksi Persampahan Dinas Pekerjaan Umum, Perumahan, Energi dan Sumber Daya Alam DIY, Sarjani, mengungkapkan dalam perhitungan terakhir volume sampah yang masuk setiap hari mencapai 450 ton ke TPST ini, maka diperkirakan usia tempat pembuangan sampah akhir ini berakhir tahun ini.

Tabel 1.2. Rekapitulasi Sampah Bulanan TPST Piyungan

Tanggal 1-31 Oktober 2018

\begin{tabular}{clrc}
\hline \hline NO & ASAL DAERAH & JUMLAH (KG) & $\mathbf{( \% )}$ \\
\hline \hline 1 & Kota Yogyakarta & $8.395,900$ & 46,16 \\
\hline 2 & Kabupaten Sleman & $5,211,490$ & 28.65 \\
\hline 3 & Kabupaten Bantul & $2,306,430$ & 12,68 \\
\hline 4 & $\begin{array}{l}\text { Non Dinas Kota } \\
\text { Yogyakarta }\end{array}$ & 335,032 & 1,84 \\
\hline 5 & Non Dinas Sleman & 287,920 & 1,58 \\
\hline 6 & Non Dinas Bantul & 46,330 & 0,25 \\
\hline 7 & Insidental & $1,606,890$ & 8,83 \\
\hline & JUMLAH & $18,189,992$ & 100 \\
\hline
\end{tabular}

Sumber : Data Pengelola TPST Piyungan (2018)

Dari data tersebut diketahui volume sampah mengalami fluktuasi dari tahun ke tahun. Meskipun sempat menurun di tahun 2008 namun mengingat areal dan kapasitas TPA Piyungan semakin berkurang, maka sampah tetap menjadi permasalahan krusial yang harus segera ditangani. Pengelolaan yang telah dilakukan oleh pemerintah masih belum sepenuhnya dapat mengatasi masalah sampah. Oleh karena itu sudah saatnya setiap lapisan masyarakat bergerak dan saling bekerja sama untuk menyelesaikan masalah tersebut. Salah satu kegiatan pendampingan selama ini yang dilakukan oleh MPM diantaranya adalah pelatihan tekhnologi informasi, pendampingan penyusunan struktur komunitas pemulung TPST Piyungan yang bernama Makaryo Adi Ngayogyakarto atau Mardiko dan penyuluhan perilaku hidup bersih dan sehat untuk anggota Mardiko dikarenakan permasalahan kesehatan di lingkungan TPST Piyungan sejauh ini sangat memperihatinkan.

Terutama akses layanan kesehatan yang belum memadai bagi masyarakat TPST Piyungan saat ini masih terbatas sehingga MPM dirasa perlu melakukan 
pemberdayaan. Sebagai salah satu contoh melakukan kegiatan secara masif gerakan mencuci tangan sebelum makan, karena selama ini pemulung sesudah memulung sampah tidak mencuci tangannya langsung menyentuh makanan.

Dalam Peraturan Daerah Kabupaten Bantul Nomor 15 Tahun 2011 tentang Pengelolaan Sampah disebutkan bentuk peran masyarakat dalam pengelolaan sampah meliputi : a) Menjaga kebersihan lingkungan; b) Aktif dalam kegiatan pengurangan, pengumpulan, pemilahan, pengangkutan, dan pengolahan sampah; c) Pemberian saran, usul, pengaduan, pertimbangan, dan dapat dalam upaya peningkatan pengelolaan sampah di wilayahnya.

Penanganan sampah di D.I.Yogyakarta selain berdasarkan perda Kabupaten Bantul diatas juga harus berdasarkan pada perundangan Perda Daerah D.I.Yogyakarta No.3 Tahun 2013 Tentang Pengelolaan Sampah Rumah Tangga Dan Sampah Sejenis Sampah Rumah Tangga, pada ayat 16 disebutkan bahawa sampah harus dipilah terlebih dahulu menurut jenis sampahnya menjadi lima; sampah yang mengandung bahan berbahaya dan beracun; sampah yang mudah terurai; sampah yang dapat digunakan kembali; sampah yang dapat didaur ulang; dan sampah lainnya.

Sesuai dengan Peraturan Daerah tersebut maka masyarakat juga memiliki kewajiban untuk mengelola sampah. Dari data sebelumnya diketahui bahwa volume sampah di TPST Piyungan sempat mengalami fluktuasi. Fenomena fluktuasi jumlah volume sampah disebabkan salah satunya karena perilaku masyarakat terhadap sampah sudah mulai berubah. Masyarakat mulai menyadari akan pentingnya melakukan pengelolaan sampah mandiri, akan tetapi kemandirian dalam pengelolaan sampah ini belum menjadi gerakan yang massive sehingga belum dapat menurunkan jumlah volume sampah secara konsisten. Selain itu ilmu dan pengetahuan masyarakat sekitar TPST Piyungan dalam mengelola sampah masih sangat terbatas.

Dengna mengacu pada gambaran lokasi tersebut, penelitian ini menggunakan metode kualitatif deskriptif dengan menggunakan beberapa teori yang berfungsi dalam mendukung temuan-temuan di lapangan yang berkaitan dengan hal yang akan diteliti. Peneliti menggunakan teori peran dalam mendukung temuan di lapangan yakni peran pemuda sebagai fasilitator pemberdayaan Teori partisipasi dan teori pemuda juga akan digunakan dalam mendukung temuan di lapangan.

\section{HASIL DAN PEMBAHASAN}

Majelis Pemberdayaan Masyarakat Pimpinan Pusat (MPM PP) Muhammadiyah dalam melakukan program pemberdayaan dibantu oleh fastor 
pemberdayaan atau sering disebut dengan istilah fastor. Fastor ini berfungsi sebagai garda terdepan karena bersinggungan langsung dengan komunitas dampingan MPM PP Muhammadiyah dan berada di luar struktur periode kepengurusan. Menurut hasil wawancara dengan Muhammad Qomaruddin, yang menyatakan bahwa:

"Fastor direkrut untuk membantu kinerja MPM, karena MPM mempunyai beberapa kelompok dampingan dan pengurus MPM juga mempunyai pekerjaan lainnya, maka direkrutlah fastor dengan dibuka pendaftaran secara umum siapapun boleh daftar, asalkan memenuhi syarat. Selama beberapa hari akan diberikan materi sesudah materi selesai diberikan maka rencana tindak lanjutnya adalah menjadi fasilitator pemberdayaannya MPM." (Wawancara Muhammad Qomaruddin, anggota divisi organisasi MPM, pada tanggal 11 Januari 2019 pukul 22.00 WIB).

MPM mempunyai beberapa kelompok dampingan seperti komunitas asongan, difabel, UKM, petani maupun pemulung sehingga dibutuhkan banyak tenaga fastor untuk melakukan pemberdayaan masyarakat. Dari tahun 20162018 telah dilakukan 2x pelaksanaan pelatihan fasilitator pemberdayaan bernama Sekam (Sekolah Kader Pemberdayaan Masyarakat) yang terbuka untuk umum guna menambah keberadaan fastor, karena fastor pada tahun sebelumnya dirasa kurang dan banyak diantaranya yang masih melanjutkan studi. Sekam I dilaksanakan pada 9-13 November 2016 di Kulonprogo Yogyakarta, dengan peserta sebanyak 54 dari berbagai perguruan tinggi se Indonesia maupun perwakilan dari organisasi masyarakat.

Setelah pelaksanaan Sekam I ini, banyak terjadi penambahan fastor baru khususnya 26 fastor dari 54 peserta berasal dari Yogyakarta dan disebar di kelompok dampingan MPM PP Muhammadiyah di wilayah Yogyakarta. Kinerja MPM PP Muhammadiyah menjadi lebih progresif karena bertambahnya tenaga baru. Pada tahun 2018, MPM PP Muhammadiyah kembali mengadakan Sekam ke II, yang dilaksanakan tanggal 5-11 September bertempat di Kalasan Sleman Yogyakarta. Peserta yang mengikuti Sekam II berjumlah 33 yang berasal dari Yogyakarta maupun daerah lain.

Rencana tindak lanjut Sekam II ini masih sama dengan Sekam I, akan tetapi Sekam II lebih difokuskan regenerasi fastor di tingkatan MPM PP Muhammadiyah, walaupun tidak menutup kemungkinan adanya peserta yang berasal dari Jawa Timur maupun daerah lainnya dengan batas usia minimal 20 tahun dan minimal sedang menempuh kuliah semester 2 .

Panitia Sekam melakukan masifikasi penyebaran informasi, pamflet ini kemudian disebar melalui media sosial maupun ada yang ditempel di kantor 
wilayah Muhammadiyah maupun dikirimkan ke organisasi otonom (Ortom) Muhammadiyah seperti IMM maupun Pemuda Muhammadiyah. Total setelah pelaksanaan Sekam I dan Sekam II, jumlah fastor terutama yang kuliah di Yogyakarta menjadi 26 orang terdiri dari berbagai perguruan tinggi.

Langkah awal yang dilakukan dengan Pembentukan Komunitas Pemulung Mardiko. Fastor yang telah selesai mengikuti Sekam akan ditempatkan di kelompok dampingan MPM PP Muhammadiyah, salah satunya di TPST Piyungan. Dalam melakukan pendampingan di TPST Piyungan terjadi banyak dinamika seperti saat pertama kali melakukan pemberdayaan, warga sekitar TPST Piyungan mengira akan ada upaya mengajak bergabung ke Muhammadiyah, padahal tidaklah demikian.

"Waktu pertama kali masuk TPST Piyungan, memang ada penolakan dari warga setempat, ada yang mengira sebagai upaya Muhammadiyah-isasi. Bahkan ada yang mengira kami sebagai bagian dari ISIS (Islamic State in Iraq and Syuriah) karena kerudung yang digunakan oleh fastor maupun pengurus MPM perempuan kebetulan memang panjang. Tetapi setelah berbagai langkah dialog yang persuasif, warga dan pengurus TPST Piyungan jadi terbuka dengan kegiatan pemberdayaan yang kami lakukan" (Wawancara Muhammad Qomaruddin, anggota divisi organisasi MPM, pada tanggal 11 Januari 2019 pukul 22.00 WIB).

Awal tahun 2015, MPM dalam hal ini fastor maupun pengurus lainnya terlibat aktif untuk menyatukan pemulung di bawah satu wadah organisasi karena sebelum MPM masuk, pemulung masih mengikuti pengepulnya masingmasing, hal ini sesuai dengan hasil wawancara dengan Muhammad Qomaruddin, anggota divisi organisasi MPM.

Setelah berhasil menyatukan pemulung dalam satu wadah komunitas, maka langkah selanjutnya adalah membentuk kepengurusan dan melakukan penguatan internal organisasi terlebih dahulu. Maryono, salah satu warga di sekitar TPST terpilih menjadi ketua Mardiko dibantu 8 pengurus lainnya yang meliputi wakil, sekretaris maupun bendahara.

Setelah struktur organisasi terbentuk, maka yang dilakukan MPM dan fastor adalah pendataan anggota. Nantinya setiap anggota akan didata dan dibuatkan kartu tanda anggota Mardiko. Anggota Mardiko kira-kira ada 500 pemulung yang terdaftar sebagai anggota berasal dari 15 pengepul. Total 15 pengepul yang 14 terdiri dari warga sekitar TPST, dan 1 orang pengepul berasal dari luar wilayah TPST. (Wawancara dengan Maryono, ketua Mardiko, pada tanggal 11 Mei 2019 pukul 09.00 WIB).

Pemulung di TPST Piyungan selain berasal dari warga setempat, ternyata banyak juga yang berasal dari berbagai daerah seperti Gunungkidul, Bantul, 
Yogyakarta, Kulonprogo Grobogan, Magelang, Klaten,Wonogiri, Blora, Riau, Flores, dan sebagainya. Sebagian pemulung yang sudah terdaftar melalui KTP berjumlah jumlah sekitar 453 orang dari total pemulung 600 orang.

Berdasarkan asal daerah dari sisi administratif, sebagian besar pemulung tidak mendapatkan akses program layanan kesehatan gratis meskipun memiliki kartu Jaminan Kesehatan Nasional sebab umumnya pemulung tetap memilih fasilitas layanan tingkat pertama (FKTP) di daerah asal sesuai alamat di KTP. Fakta lain juga bahwa mulai 2016, berdasarkan Peraturan Menteri Sosial bahwa pemulung tidak masuk dalam kelompok Penyandang Masalah Kesejahteraan Sosial (PMKS) sehingga tidak berhak mendapatkan berbagai program dari pemerintah. Lingkungan tempat kerja yang kotor dengan perilaku hidup yang kurang sehat menyebabkan potensi pemulung terserang berbagai penyakit sangat besar.

Pada awal berdirinya Mardiko, pihak MPM dan Mardiko sempat melakukan audiensi dengan pengurus TPST untuk memperkenalkan diri untuk kembali meyakinkan pengurus TPST bahwa yang dilakukan oleh Mardiko ini tidak mengganggu kinerja pemungutan sampah, karena sempat ada kekhawatiran dari pengurus TPST seperti itu dan sebagai upaya untuk meminta bantuan kantor atau sekretariat yang bisa untuk digunakan.

Langkah berikutnya berupa Keterlibatan Aktif Fasilitator dalam Kegiatan Pemberdayaan. Wujud dari keterlibatan tersebut berupa Pelatihan TI bagi Anggota Mardiko. MPM bekerjasama dengan Prodi Ilmu Komunikasi Universitas Aisyiyah Yogyakarta mengadakan pelatihan TI (tekhnologi informasi) kepada pemulung anggota Mardiko. Para pemulung dilatih secara dasar menggunakan komputer/laptop seperti membuat surat undangan menggunakan Microsoft Word, maupun mematikan dan menyalakan komputer. Hal ini dilakukan karena sebagai komunitas baru, perlu adanya pengenalan dasar komputer bagi seluruh anggota. Pelaksanaan pelatihan TI dilakukan tiap Sabtu malam sesudah sholat Isya selama 2 dari Januari - Februari 2017.

Kegiatan pelatihan ini selain sebagai pengenalan dasar komputer ke anggota Mardiko, ternyata sangat bermanfaat bagi para pemulung, Saat pelatihan berlangsung para pemulung selalu bertanya jika ada yang dirasa kurang paham. Dulunya pemulung tidak bisa mengoperasikan TI lalu dilatih oleh MPM untuk mengoperasikan TI, sekarang pemulung sudah bisa walaupun cuma sedikit. (Wawancara dengan Maryono, ketua Mardiko, pada tanggal 11 Mei 2019 pukul 09.00 WIB).

Wujud yang kedua berupa Pertemuan Rutin Pengurus Mardiko dan Fasilitator. Pertemuan rutin biasanya dilakukan selapan/35 hari untuk 
membahas dinamika kelompok maupun program yang akan dilakukan oleh MPM di TPST Piyungan. Fastor berperan aktif menyampaikan hasil rapat internal MPM yang rutin dilaksanakan setiap Sabtu sore.Pertemuan rutin Mardiko ini dihadiri oleh anggota Mardiko, pengepul, tokoh masyarakat yang berada di sekitar TPST Piyungan. Pertemuan dilakukan pada malam hari sesudah sholat Isya karena jika dilakukan pada siang hari, pemulung banyak yang tidak bisa untuk menghadiri.

Dalam pertemuan ini dibahas mengenai masalah yang sedang dihadapi Mardiko maupun masyarakat. Masyarakat yang hadir juga membawa uang untuk iuran, terutama iuran untuk mengisi bak air yang sudah dibangunkan oleh MPM bekerjasama dengan UMY maupun Lazismu DIY.

Wujud berikutnya melakukan Pemeriksaan dan Penyuluhan Kesehatan bagi Anggota Mardiko. MPM PP Muhammadiyah bekerjasama dengan Universitas 'Aisyiyah Yogyakarta dan RS PKU Yogyakarta mengadakan pemeriksaan dan penyuluhan kesehatan gratis bagi anggota Mardiko dan pemulung sekitar TPST Piyungan. Kegiatan ini berlangsung pada hari Minggu, 27 Maret 2017. Dalam pemeriksaan ini, yang dilakukan pemeriksaan golongan darah, gula darah, asam urat dan kolesterol. Pemeriksaan kesehatan ini diikuti kurang lebih 500 peserta, tidak semua anggota Mardiko mengikuti pemeriksaan kesehatan tersebut.

Pemeriksaan dan penyuluhan kesehatan ini dilakukan karena pola hidup maupun pola makan pemulung yang tidak sehat, seringkali sesudah memulung sampah, pemulung tidak cuci tangan melainkan tangan hanya dibungkus platik saja. Padahal di TPST juga banyak sapi yang berkeliaran, maupun sampah berserakan. Dulunya para pemulung banyak terserang penyakit diare, muntaber dan gatal-gatal sekarang sudah berkurang sama sekali. (Wawancara dengan Maryono, ketua Mardiko, pada tanggal 11 Mei 2019 pukul 09.00 WIB).

Hasil yang diharapkan dengan adanya pemeriksaan kesehatan ini adalah pemulung menjadi sadar akan pentingnya kebersihan, terutama mencuci tangan setelah melakukan aktivitas. Penanaman menjaga kebersihan ini juga sebagai edukasi ke masyarakat sekitar TPST, meskipun sehari-hari berkutat dengan sampah menjaga pola hidup bersih tetap harus diutamakan.

Tim pemberdayaan bersama masyarakat juga melakukan Pembangunan Bak Air untuk Cuci Tangan Pemulung. MPM bekerjasama dengan LazisMu dan UMY melakukan pembangunan bak air untuk cuci tangan guna mendukung pentingnya budaya sadar kebersihan. Dibangun di atas tanah warga yang bersedia menyerahkan tanahnya, bak mandi ini dibangun dengan dekat dengan lokasi pengepul sehingga harapannya pemulung yang baru saja memulung bisa 
mencuci tangannya sebelum makan. Dalam pengisian air, para pemulung yang tergabung dalam komunitas Mardiko iuran untuk beli air 1 truk. Biasanya 2 minggu sekali truk isi air akan datang dan mengisi bak cuci tangan tersebut. Para pemulung juga menggunakan air dari bak cuci tangan ini sebagai air wudhu seperti hasil wawancara dengan Pak Maryono ketua Mardiko.

"Bak cuci tangan ini sangat berguna sekali, dalam artian dulu pemulung makan hanya memakai tangan dibungkus plastik, dengan adanya padasan (bak cuci tangan) Alhamdulillah sekarang pemulung kalau makan tidak usah memakai plastik lagi, tetapi cuci tangan dengan memakai sabun. Lebih sehat dan lebih hemat, selain itu juga sebagai tempat untuk mengambil air wudhu dulunya pemulung tidak menjalankan sholat 5 waktu Alhamdulilah sekarang sudah bisa menjalankan sholat 5 waktu." (Wawancara dengan Maryono, ketua Mardiko, pada tanggal 11 Mei 2019 pukul 09.00 WIB).

Para pemulung setiap hari mengumpulkan sampah plastik, kertas/karton, botol dengan cara memungut di tumpukan sampah yang setiap hari masuk di TPST Piyungan. Dalam melaksanakan pekerjaannya ini, pemulung bercampur dengan ribuan ekor sapi yang mencari makan di tumpukan-tumpukan sampah. Berdasarkan informasi dari Sekretariat Bersama Yogyakarta, Sleman, Bantul (Sekber Kartamantul), keberadaan pemulung dalam TPST Piyungan mempunyai kontribusi terhadap pengurangan volume sampah di TPS Piyungan sebanyak 4800 ton per tahun sehingga TPST Piyungan tidak cepat penuh. Dengan fakta ini maka pemulung dapat dikategorikan sebagai "Pahlawan Lingkungan". Pahlawan Lingkungan yang berperan dalam mengurangi volume sampah di Tempat Pembuangan Akhir. Salah satu isu penting bagi pemulung adalah pemberdayaan kesehatan pemulung sebab pekerjaan pemulung di TPST Piyungan mempunyai dampak dan resiko yang sangat besar terhadap kesehatan.

Setiap hari pemulung bekerja di lingkungan yang kotor penuh tumpukan sampah, menghirup gas metan, sanitasi air yang buruk, ketersediaan air bersih sangat terbatas, sarana prasarana mandi cuci kakus (MCK) di lokasi kerja belum tersedia, dan sebagainya. Dengan kondisi seperti itu, mencuci tangan pasca bekerja memulug sampah belum menjadi kebiasaan. Saat istirahat dan waktunya makan maka pemulung akan langsung menikmati bekal makanan yang dimiliki tanpa melakukan cuci tangan apalagi membersihkan badannya terlebih dahulu. Dapat dibayangkan kuman atau bakteri yang menempel di kuku atau tangan pemulug tertelan masuk bersama makanan yang dikonsumsi setiap hari saat bekerja di TPST Piyungan. Cuci tangan merupakan hal sepele bagi sebagian orang namun ternyata tidak bagi pemulung sebab di samping faktor rendahnya 
kesadaran akan pentingnya cuci tangan juga sarana prasarana cuci tangan yang tidak tersedia di sekitar tempat bekerja.

Kondisi itu sudah terjadi semenjak pemulung datang mengais rejeki di TPST Piyungan yaitu pada kisaran 15-22 tahun yang lalu. Dengan rutinitas pekerjaan tersebut dan jangka waktu yang sudah cukup lama, pemulung merasa bahwa kondisi kesehatannya tidak terganggu dan baik-baik saja. Padahal faktanya bahwa berdasar hasil diskusi dengan beberapa tokoh masyarakat, selama ini banyak pemulung yang batuk tidak sembuh-sembuh, sesak nafas, gatal-gatal, sakit perut dan sebagainya. Bahkan tanggal 22 Maret 2017 ada pemulung yang meninggal disebabkan oleh diabetes yang tidak diketahui sebelumnya.

\section{KESIMPULAN}

MPM melakukan pemberdayaan di TPST Piyungan dengan garda terdepannya melalui pemuda yang tergabung dalam fasilitator pemberdayaan. Dalam pelaksanaannya, MPM secara perlahan berhasil merubah pola pikir masyarakat di sekitar TPST, antara lain dengan membiasakan diri cuci tangan, terbiasa menggunakan komputer secara dasar dan perilaku hidup sehat. MPM melalui fasiliator juga memfasilitasi pembentukan komunitas pemulung, komunitas yang dimaksut untuk mewadahi pemulung agar mudah MPM mudah dalam melakukan pemberdayaan. Tak dapat dipungkiri peran serta masyarakat juga mempunyai andil dalam keberhasilan program ini.

\section{DAFTAR PUSTAKA}

Agus Surjono, \& Trilaksono Nugroho, Paradigma, Model, Pendekatan Pembangunan, dan Pemberdayaan Masyarakat di Era Otonomi Daerah, (Malang: Bayumedia Publishing, 2008)

Basrowi dan Suwandi. 2008. Memahami Penelitian Kualitatif. Jakarta: PT. Rieneka Cipta.

Burhan Bugin, (2007) Penelitian Kualitatif, Jakarta: Perenada Media Group,

Goffman, Erving. 1959. The Presentation of Seelf in Everyday Life. Jakarta: Erlangga. 
Dewi, M.H.U. 2014. Partisipasi Masyarakat Lokal dalam Pengembangan Desa Wisata di Kabupaten Tabanan, Bali. Disertasi: Universitas Gadjah Mada

Hari Witono, dkk, (2006) Pemberdayaan Masyarakat Modul Para Aktivis Masyarakat, Sidoarjo: Paramulia Press

Huda Miftachul, Pekerjaan Sosial \& Kesejateraan Sosial SEBUAH PENGANTAR Edi Subarto, (Yogjakarta: Pustaka Pelajar, 2009),

Mulansari SA, Husodo AH dan Muhadjir N. 2014. Kebijakan Pemerintah dalam Pengelolaan Sampah Domestik. Jurnal Kesehatan Masyarakat Nasional, 8 (8)

Moleong, L. (2013). J. 2007. Metodologi penelitian kualitatif

Nadhir Muhammad, Memberdayakan Orang Miskin Melalui Kelompok Swadaya Masyarakat (Sidoarjo: Yapsem, 2009)

Suharto Edi, Membangun Masyarakat Memperdayakan Masyarakat, (Bandung: Refika Aditama, 2005)

Soekanto, Soerjono. 2002. Sosiologi Suatu Pengantar, Jakarta: Raja Grafindo Persada

Soetrisno, L. (1995). Menuju masyarakat partisipatif. Penerbit Kanisius

Sugiyono.2006. Metode Penelitian Kuantitatif, Kualitatif dan Kombinasi Mixed Methods). Bandung: Alfabeta.

Suharto, Edi. 2009. Membangun Masyarakat Memberdayakan Rakyat: Kajian Strategis Pembangunan Kesejabteraan Sosial \& Pekerjaan Sosial. Bandung: Refika Aditama.

Peraturan Daerah Kabupaten Bantul Nomor 15 Tahun 2011 tentang Pengelolaan Sampah

\section{Website :}

www.dlh.bantulkab.go.id/, Bantul Tahun 2016, Diakses pada 22 Mei 2018 pukul 07.30 WIB, melalui 
https://dlh.bantulkab.go.id/filestorage/dokumen/2017/03/IKPLHD\%2 02016.pdf

www.jogja.tribunnews.com/ http://jogja.tribunnews.com/2015/12/31/lipsussampah-semakin-menggunung-di-tpstpiyunga

www.yogyakarta.bps.go.id/, Mei 2018 pukul 21.00 WIB, melalui http://yogyakarta.bps.go.id/website/pdf_publikasi/StatistikDaerahIstimewa-Yogyakarta-2016. 